\title{
Developing Sino-Israeli Relations in the Post-Cold War Era: Analyzing Desecuritization Scenarios for Iran
}

Fariborz Arghavani Pirsalami, Seyed Javad Salehi, Hossein Alipour

Shiraz University, Iran

\begin{abstract}
An important feature of Israel's foreign policy in the post-Cold War era has been development of relations with emerging powers, including China. The importance of the economic component in the foreign policy of both countries, China's efforts to achieve the status of a great power, and Israel's strategies to improve its global image and regional position have brought the two countries' relations into a form of comprehensive cooperation in the post-Cold War era. Describing the relations between the two countries in the political, military and economic spheres and acknowledging the impact of China and Israel's behavior patterns on national and regional security of Iran the article seeks to answer the following questions: What are the indicators of the development of China-Israel relations in the post-Cold War era? What are the consequences of these relations for Iran? From this article's point of view, the development of China-Israel relations in all areas has been on an upward trajectory and hence have substantial implications at the national (threatening China-Iran relations in the field of energy and weakening Iran-China military relations and enfeebling Iran's position in the Silk Road project), regional (changing the balance to the detriment of Iran, Iran's containment and normalization of Arab-Israeli relations) and international levels (China's accompanying pressures on Iran, Israel's use of China's capacity in international institutions and efforts to legitimizing and reinforcing the notion of Iran's threat and continuing Iranophobia) for Iran's security.
\end{abstract}

Key words: China, Israel, Iran, the Middle East, Security, Foreign Policy.

I

$\mathrm{n}$ the post-Cold War era, one of the most important aspects of Israel's foreign policy has been widespread cooperation with emerging powers, largely due to the end of the rigid blockings of the Cold War on the one hand and its regional isolation and the difficulty of its integration into the Middle East on the other. Israel's dramatic 
progresses in advanced technologies in the fields of military, energy, agriculture and information sectors are the main causes that have attracted the attention of emerging powers. One of the emerging powers whose relations with Israel have reached unprecedented levels is China. Since late 1970s, along with economic reforms it has changed its relations from nonrecognition to comprehensive cooperation with Israel. China needs advanced Israeli technology in its quest for the status of a great power and modernization, especially in the military field. With the West refusing to transfer military technology to China, Israel is the only way to fill that gap. On the other hand, Israel needs to expand its relations with China in various areas in order to improve its regional position and global image. China is also a big market for Israel. The \$ 14 billion trade volume between the two countries, massive investments, scientific-academic and cultural partnerships show that relations between the two countries in the post-Cold War era have shifted to a form of inclusive cooperation (Evron 2017b: 828).

On the other hand, the Islamic Republic of Iran has extensive relations with China. Iran also has advantages for China that cannot be easily ignored. The abundance of energy resources, the large consumer market, regional power, and Iran's revisionist approach to the existing international order are significant to China. The Islamic Republic, which has been subject to Western sanctions due to its revisionism, views China as a strategic partner that can act as a balancer against the West, especially the United States that could be a good substitute for them to provide the resources needed to modernize Iran in different areas. The experience of Iran's nuclear program and Iran's membership in the Shanghai Organization have shown that the Islamic Republic's perception of China as a strategic partner is completely false, leading to Iran becoming a playing card for this country (Arghavani 2015: 168-170). Indeed, there are fundamental differences in the foreign policy of China and Iran. China's foreign policy is not designed to be a direct challenge to the US hegemony, and in its bilateral relations with Iran it is trying to take into account the concerns of the United States and Iran's neighbors. While Iran's foreign policy has remained ideological but regardless of its existing contexts and risks, unilaterally regards China as a strategic partner. At the same time, the issue of large-to-medium power asymmetry between the two countries has also become a contradiction (Chau, Kane 2014: 259-63).

On the other hand, relations between Iran and Israel have been severed after the Islamic Revolution because of the changes in Tehran's foreign policy. The Islamic Republic explicitly supports the ideals of Palestine and Palestinian groups and even calls for the destruction of Israel. Iran's nuclear crisis, its support for Palestinian militant groups, Israel's efforts to identify Iran as the cause of regional instability and failures in the Middle East peace process, and Israel's destructive role in Iran-US relations, have exacerbated relations between the two countries. Israel is pursuing active diplomacy aimed at pushing China and Russia away from Iran to complete pressure on this country. So, one of the main reasons for Israel's proximity to China is to negotiate with Beijing over Iran (especially its regional role and missile issues) in order to persuade one of the major powers close to Iran to a consensus against it (Chau, Kane 2014: 259-63). 
Although there are researches on the bilateral relationship of each of these three sides, the simultaneous examination of the three has not received much attention. Aron Shai in China and Israel (1890-2018) has examined relations between the two countries since the presence of Jewish communities in China and has covered all aspects of the two countries' relations. Anoushiravan Ehteshami and Niv Horesh (Ehteshami, Horesh 2018) have analyzed the relations between the two countries under the Belt and the Road Initiative and have only considered the economic aspects of the parties' relations. There have also been numerous articles on China-Israel relations. Yoram Evron (Evron 2017b: 828) has analyzed the dramatic growth of the two countries' relations with emphasis on economic dimensions. Islam Ayyadi \& Mohammed Kamal (Ayyadi, Kamal 2016) have only scrutinized the military relations of the two countries, especially in the area of Israeli military technology transfer to China and the role of the United States in halting such cooperation.

Given the lack of Persian literature on Chinese-Israeli relations and due to the significance of this field in Iranian foreign policy, national security, and regional security, an independent research on this case is needed. This article, after describing the relations between the two countries in the political, military and economic spheres and acknowledging the impact of China and Israel's behavior patterns on national and regional security of Iran, seeks to answer that what are the indicators of the development of China-Israel relations in the post-Cold War era? And what are the consequences of these relations for Iran? From this article's point of view, the development of China-Israel relations in all areas has been on an upward trajectory and hence have substantial implications at the national level (threatening China-Iran relations in the field of energy and weakening Iran-China military relations and enfeebling Iran's position in the Silk Road project) regional (changing the to the detriment of Iran, Iran's containment and normalization of Arab-Israeli relations) and international (China's conscious passivity and accompanying pressures on Iran, Israel's use of China's capacity in international institutions and efforts to legitimizing and reinforcing the notion of Iran's threat and continuing Iranophobia) for Iran's security.

In order to prove the article's claim, the Middle East's position in Chinese foreign policy and then the various aspects of China-Israel relations will be explored and then the consequences of the two countries' relations on Iran's security will be examined.

\section{China and the Middle East in 21st Century}

China which has changed its foreign policy strategy in the light of economic reform, is also taking a special look at the Middle East region, and its relationship with the region in the 21st century has taken a new form and entered a new phase (Sazmand, Arghavani 2017: 191-92) The reasons for the region's growing importance to China in the postCold War era can be attributed to the following political and economic interests:

Economic interests: Since the beginning of economic reforms, the role of economic variables in Chinese foreign policy has been very vital and its main focus has been 
on domestic and international stability to improve economic development. China's continued economic growth requires two key elements that have doubled the importance of the Middle East for this country. The first element is China's growing need for energy imports, especially crude oil (Kim, Mohaisen 2016: 5). Figure 1 shows China's growing oil imports.

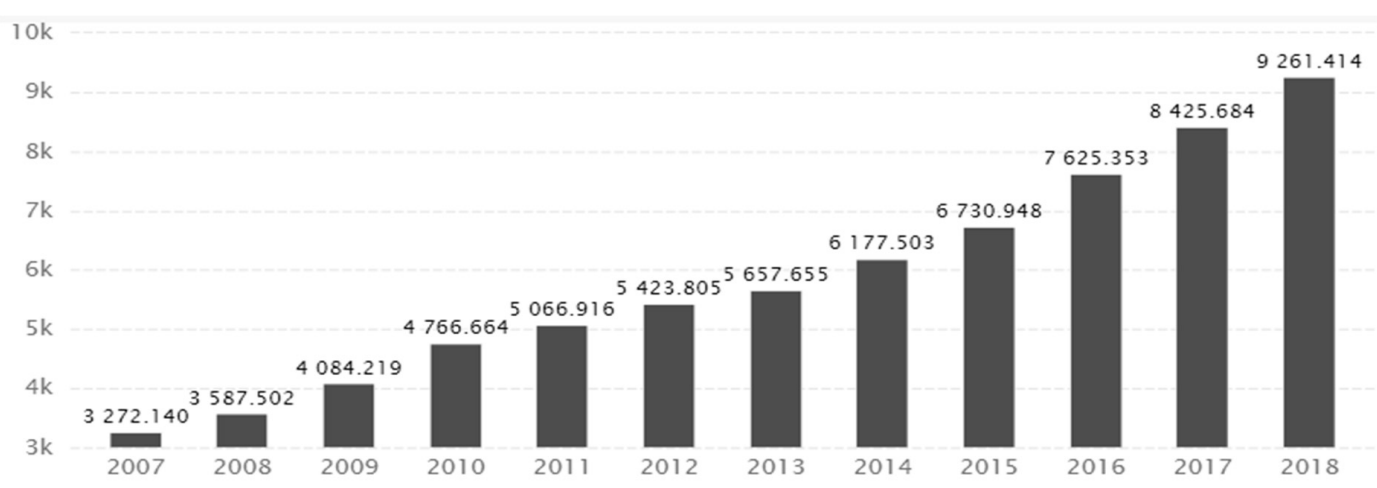

Figure 1: China's Oil Imports in 2007-2018 (Billion Barrels)

Source: Global Economic Data, 2019

The Middle East is at the center of China's focus on energy imports. The region holds 56 percent of proven oil reserves and 42 percent of the world's proven gas reserves. Currently, 52 percent of China's oil imports come from the Middle East and forecasts suggest that this rate will rise to 72 percent in the third decade of the 21 st century. Trade and investment are the second factors that make the Middle East important to China. The region has a large market and mainly the importer of industrial goods. China is now the region's second largest trading partner behind the United States. China's exports to the region in 2018 are reported to exceed \$ 125 billion, and its investment in the region has reached \$ 160 billion (2018) (Javaid, Meer 2016: 705-706).

Political interests: This type of Beijing interests in the region depends on various factors. The first is stability in the Middle East, whose fragile situation threatens China's economic interests, especially its energy security. China strives to maintain stability and balance in the region by maintaining friendly relations with all the governments of the region, and especially the major powers (Ponížilová 2019: 643). The second factor is the ethnic and religious affiliation of Chinese minorities with the countries of the region, which has made the Middle East an immediate neighborhood to China. This country fears infiltration Islamic extremism into the Uyghur minority, especially as they tend to radical readings of Islam and tens of thousands of them have been participating in groups such as al-Qaeda and ISIS. China's strategy among these minorities is repression and forced integration. Because this strategy raises the sensitivity of Muslims, Beijing is trying to prevent the global mobilization of Muslims and internationalization of this issue by maintaining friendly relations with the Muslim countries of the region (Scobell 2018: 15-17). 
The desire to be identified as a responsible great power and to meet the expectations of the international community is the third factor that makes the region politically significant. Western governments believe that China is reluctant to carry out its responsibilities and spending on peace and stability in the Middle East and refer to this as free riding. They insist that Beijing uses Western spending to stabilize the region and refuses to take security responsibilities. This debate has been particularly prominent since 2013, with China being called the primary beneficiary of the order that the United States maintains in the region. But China's elites have rejected the issue and persist that this country is the victim of instability in the region because the US has made mistakes that have caused more turmoil which have increased energy prices (Jin 2017: 40-41). Chinese authorities argue that their approach to participate in the political and economic governance of the region is fundamentally different from that of western governments. They see the root of the region's problems as economic underdevelopment and believe that improving living standards and welfare levels will promote regional stability and security of regional governments. They disagree with Western approaches to resolving regional problems and by citing the experiences of Afghanistan, Iraq and Libya argue that the West has exacerbated the security situation in the region (Dorsey 2017: 8).

\section{China and Israel: From non-recognition to inclusive cooperation}

During the struggles between the Communist and nationalist forces to control mainland China, Jewish activists and Chinese nationalists supported each other and even formally recognized each other. The goal of the Jewish activists in these relations was to pave the way for expediting the migration of Jews residing in China to Israel, as the largest East Asian Jewish community resided in China, whose population had grown after World War II. Following the establishment of the State of Israel (1948), during voting for Palestinian partition plan, Republic of China with its abstention paved the way for the project to be approved (Goldstein 2004: 235-237). But communist domination over China and the establishment of a communist regime led by Mao Zedong changed China-Israel relations. Israel was the first Middle East government to recognize the new Chinese system in 1950 but the People's Republic of China (PRC) did not reciprocate. Israel sought formal relations with the PRC for two main reasons; the first being China's growing influence and capacity in the international system that could support Israel's security concerns. The second reason was to attract economic aid and accelerating the migration of Jewish communities in China to Israel (Sufott 2000: 95). The outbreak of war on the Korean Peninsula and opposition from pro-US groups were Israel's most significant barriers to formal relations with the PRC. Communist China was reluctant to establish relations with Israel too. At the time, to the Chinese leaders, Israel was the instrument of imperialism and the illegitimate son of the capitalist system in the region. Despite sending numerous messages from Israel to China to establish relations, the PRC was not willing to formally engage with 
Israel under the influence of two factors; One of these factors was the Bandung conference, which brought China closer to the Arabs and intensified its anti-Israeli policies. China's isolation due to the Cultural Revolution was another factor that pushed this country further away from Israel (Shichor 2015: 141). Figure 2 illustrates the limiting factors of China-Israel relations during the Cold War.

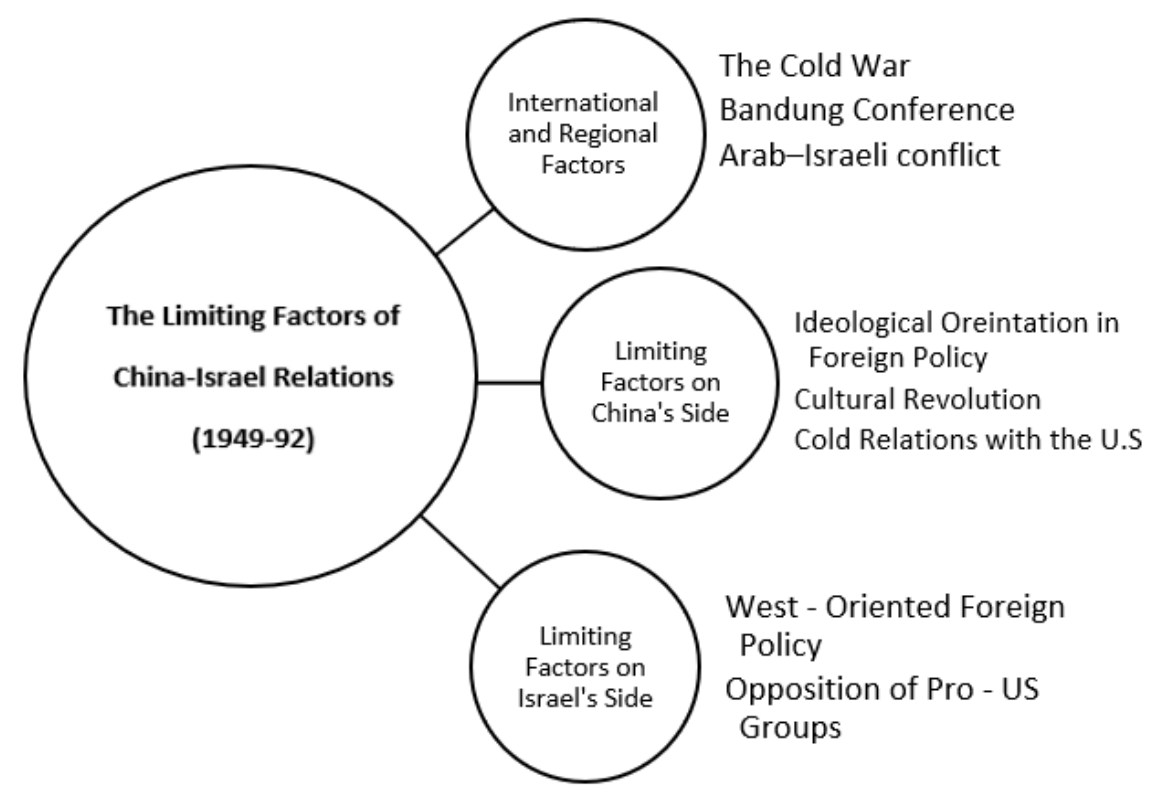

Figure 2: The Limiting Factors of China-Israel Relations (1949-92)

Source: Compiled by Authors

But since the 1970s, positive developments have taken place in the relations of two countries. Improving China-US relations, the Camp David Accords and the Madrid Peace Conference led China and Israel to start informal contacts. Since then, representatives of the two countries met in international forums, and even an Israeli business board traveled to China. During Sino-Vietnamese War a new era of China-Israel relations began. The Chinese military needed technical and military assistance, and since it used Soviet-made weapons, Israel was able to meet the needs of China because of its familiarity with those weapons. This military cooperation was brokered by an active Jewish businessman in East Asia named Shaul Eisenberg. In this partnership, Israel upgraded China's T59 tanks. Mao's death was another factor that made it possible to improve these relations. The change of leadership and reforms of Deng Xiaoping led world-wide measures to improve China's economic situation and international relations. After then, due to its strategic relationship with the United States as well as significant advances in military technology Israel attracted Beijing attention (Shai 2014: 73). Formal diplomatic relations between the two countries officially began in 1992, and since then, China-Israel relations have grown rapidly in all areas. 


\section{China and Israel in the post-Cold War era}

Political and Diplomatic Relations: This type of China - Israel relationship has experienced significant growth and senior officials from the two countries have met regularly. Chinese officials have traveled to Israel 13 times, the most notable of which was President Jiang Zemin's 2000 trip to Israel. Other trips have been made at the level of the Foreign Minister and the Deputy Prime Minister. But the Israeli side has been more active in that relations, with 19 official visits to China, including five visits by the President and Prime Minister and 14 visits by various ministers (Efron et al. 2019: 48-50). Another major Israeli move is to establish consular offices in Shanghai, Guangzhou and Chengdu (Xiao 2016: 4).

Relations between the two sides have now improved in the light of a pragmatic foreign policy and economic orientation and the separation between political and economic issues. But the two countries pursue different goals in developing relations; Israel is looking for new allies that could be used as a balance against European pressures and dependence on the United States. Israel can enjoy a variety of political and economic benefits by developing relations with emerging powers such as China, India and Russia. In the political dimension, Israel could gain the support of these powers in regional conflicts and persuade them to put pressure on its enemies in the region (including Iran). So, one of Israel's important goals in improving its relations with China is to influence its Middle East policies. On the economic front, these countries also represent a huge market for Israel's advanced technologies, both military and civilian. Israel seeks to create a kind of dependence on emerging powers, including China, that ties their economic interests to its stability and security (Agdemir 2016: 55-57). China also pursues specific goals of developing relations with Israel. Its most prominent goal is to achieve Israel's state-of-the-art technology that is essential to China's modernization process. Israel has these technologies in a variety of fields, including military, energy, agricultural and medical. With the West refusing to transfer dual-use technologies to China, Israel can act as a supplier of these technologies to Beijing. Israel's second most important feature for China is its strategic relationship with the United States and its powerful Jewish lobby in this country. From the Chinese leaders' point of view, Israel can play a constructive role in US-China relations. The importance of this issue is further accentuated by the restrictive role the United States plays in the transfer of military technology from Israel to China. China's third target for improving relations with Israel is the concern that this country could transfer advanced military technologies to China's neighbors and rivals in East and South Asia. Beijing is particularly sensitive about the transfer of these military technologies to Taiwan and India. Under China's pressure, Israel has halted the transfer of these technologies to Taiwan, but India remains one of the largest purchasers of advanced military weapons from Israel, while Beijing is barred from such relationships. This changes the balance in China-India relations, which have some discords ${ }^{1}$.

\footnotetext{
1 Border disputes and strategic rivalries between the two countries to influence different areas, especially in South and Southeast Asia, are the most important accords between them.
} 
Since the beginning of the new millennium, there have been two major issues in China's and Israel's political divisions: the Palestinian issue and China-Iran relations. China has appointed a special envoy to the Arab-Israeli conflicts in the new millennium to mediate them through increased diplomatic activities. By presenting its plans and proposals, China is working to ease the tensions and advance the peace process. President Xi Jinping, who separately hosted Israeli Prime Minister and Chairman of the Palestinian National Authority in 2013, presented a four-point plan to resolve the conflict. The plan included the establishment of an independent Palestinian state (based on pre-1967 borders), respect for the existence, legitimacy and security concerns of Israel, negotiations as the only solution to the immediate cessation of violence against civilians and settlements, land for peace principle and greater involvement of the international community to advance the peace process. In 2017, when Beijing was once again host to both sides, by insisting the initiative, added a new article to the plan that addresses conflict resolution through economic development. Promoting economic cooperation, improving the welfare of Palestinians, interactions between people and a proposal to establish a tripartite cooperation forum are included in this article (Evron 2017a: 130-132).

Another issue between China and Israel is China's relations with Iran. They have different views on resolving Iran's issues. While Israel supports pressure and coercion to contain Iran, China has always insisted on resolving Iran's problems through peaceful and diplomatic means. So, Israel tries to persuade China to limit its relations with Iran and bargains over it (The details will be discussed in more details in Section 4). In summarizing the political relations between China and Israel, it should be noted that these relations by Israel are focused on influencing China's Middle East policies as well as the use of China's capacities in international and regional equations. China's focus is on acquiring Israeli advanced technologies for economic and military modernization. However, the issue of Palestine and China-Iran relations are the most controversial issues between two countries that sometimes cause divergences in their relations.

\section{Military-security relations in the post-Cold War era}

Israel's dramatic development in the military industry has attracted China's attention to fill this gap with the West. To achieve the position of a great power, China must modernize the People's Liberation Army. Following Tiananmen Square protests that led to the West boycotting China's weapons, Israel became the second supplier of weapons to China after Russia. China and Israel are both exporting and importing weapons. Exact statistics on Chinese arms imports from Israel are not available. In addition to the nature of this type of relationship, which is often associated with lack of transparency, another factor that leads to lack of information on this issue is the US sensitivity and opposition to China-Israel military cooperation. The United States argues that such cooperation will change the strategic balance in East Asia, and in particular in the Taiwan Strait in favor of China (Olimat 2013: 261-62). 
Military exchanges between the two countries began in the late 1970s. China, which was in difficulty in the Vietnam War (1979), sought military and technical assistance. In this collaboration, Israel provided the Chinese Army with a rebuilt $105 \mathrm{~mm}$ cannon (Shai 2014: 73). There are reports that the two countries have had 60 arms deals from 1979 to 2000, estimated between $\$ 3$ billion and $\$ 4$ billion. These deals included: Air-to-air (Python 3) missiles sales to China, Anti-tank missiles sales to China, Harpy and Kfir aircraft sales to China, upgrading the MiG aircrafts, J-10 aircraft design (based on Levi Project), Designing Missile Technology for CSS-2, Intermediate-Range Ballistic Missile, and DF15, Short-Range Ballistic Missiles, Selling Gabriel missiles, Development of surface-to-air missiles (PL-8H) and air-to-air missiles (PL9), sales of spyware, refueling technology, radar technology for submarines, F-62 tanks rebuilding and Merkava tanks sales (Shichor 1998; Ayyadi, Kamal 2016: 263).

Several arms deal between the two countries were also canceled by direct US intervention. In 2000, under pressures from the United States, Israel announced that would not be able to supply Falcon aircraft to China. The United States opposed the deal, arguing that it would alter the strategic balance in the Taiwan Strait in favor of China. This country threatened to cut military and economic aid to Israel if the treaty would not terminate. Israel's Prime Minister Ehud Barak, seeking full US support for negotiations with the Palestinians, terminated the deal and it forced Israel to pay \$ 350 million in compensation to China (Evron 2013: 511).

The second controversy between the two countries was in 2005. Israel had agreed to repair the Harpy aircraft that it sold to China in the 1990s. The United States demanded that the planes not be returned to China. In the end, it was not clear whether Israel repaired the planes or returned them to China without repair. The US then called for a complete halt to Israeli arms sales to China, and called on the Israeli government to provide the US government with a full report on technology transfers to China. The United States and Israel signed a Memorandum of Understanding on the Need for US Approval to Sell Any Military or Dual-use Technologies of Israel to China, which implemented tough policies to ban technology transfer to China (Rajiv 2017: 419).

Existence of some Chinese weapons in the hands of Hamas and Iran's nuclear program has forced Israel to alter security-defense relations with China (Chau, Kane 2014: 259-261). The first 'China-Israel Security and Strategy' Symposium was held in 2011 at the Interdisciplinary Center Herzliya by the Centre for Global Research in International Affairs and the International Institute for Counter-Terrorism (ICT), which indicates China's interest in using Israel's experiences in dealing with unrest among Muslim minorities. Senior military officials' meetings have resumed since 2011 as well. The Israeli Defense Minister traveled to China in 2011. Despite the lack of signs of technology transfer, three weeks after the trip, Israeli industries were bidding to establish a center for the production of fighter aircrafts. The chief of staff of the People's Liberation Army also visited Israel that year. In 2012, Qingdao Guided-Missile destroyer docked in Haifa port, northern Israel, with a battleship and a Chinese Navy ship (Rabkin 2013: 114). 


\section{Economic relations in the post-Cold War era}

Since the beginning of China's reforms, economic diplomacy has become an important aspect of its foreign policy. Beijing is looking for markets to sell its products as well as attracting advanced technologies. Israel is important to China in this regard, and there are two main reasons for the growing economic ties between the two countries; first, their economy is complementary. Israel is an exporter of technology and an importer of capital, and China is an exporter of capital, industrial goods and labor. The second reason is their pragmatic foreign policy. Despite controversy over military cooperation between the two countries, they have separated political and economic issues from one another and have not allowed these differences to harm cooperation in other areas. In fact, China understood Israel's restrictions on military cooperation and then focused on economic cooperation (Evron 2017b: 828-829).

Bilateral trade: The trade relations between the two countries have grown rapidly and have almost doubled since 1992. Currently, China is Israel's largest trading partner in Asia and its fourth largest export partner globally (Chaziza 2018a: 33). Table 1 shows China's position among Israel's top trading partners.

Table 1: China's position among Israel's top trading partners

\begin{tabular}{|c|c|c|c|}
\hline Country & $\begin{array}{c}\text { The Portion among Israeli import } \\
\text { partners (\%) }\end{array}$ & Country & $\begin{array}{c}\text { The Portion among Israeli export } \\
\text { partners (\%) }\end{array}$ \\
\hline USA & 11.7 & USA & 28.8 \\
\hline China & 9.7 & England & 8.2 \\
\hline Switzerland & 8 & Hong Kong & 7 \\
\hline Germany & 6.8 & China & 5.4 \\
\hline
\end{tabular}

Source: CIA-World Fact Book, 2018

Israel's exports to China were valued at \$ 4.794 billion in 2018. China's exports to Israel also valued at $\$ 9.315$ billion in $2018^{2}$. Figure 3 shows the volume of trade between the two countries.

Investment: About 42 Chinese companies operating in Israel invested approximately $\$ 12$ billion between 2007 and 2018 (Efron et al. 2019: 82). In 2011, ChemChina company acquired $60 \%$ of Makhteshim-Agan, the largest Israeli company in the field of chemicals and pesticides. Another major investment of China is the acquisition of 51\% of Tnuva (Israel's largest food processing company) (Shai 2019: 226-229). In 2013, the two sides signed the 'Water Technology City' Agreement which has selected Shandong Province as the project site. Accordingly, China draws on Israeli experiences in desalination, irrigation, recycling and water treatment (Xiao 2016: 16-18). In the field of energy, the parties have expanded research and development collaborations and established a fund for renewable energies. China seeks to utilize Israel's expertise

2 Trade Map. 2018. Yearly Time Series'. URL: tradingeconomics.com (accessed 20.06.2020). 


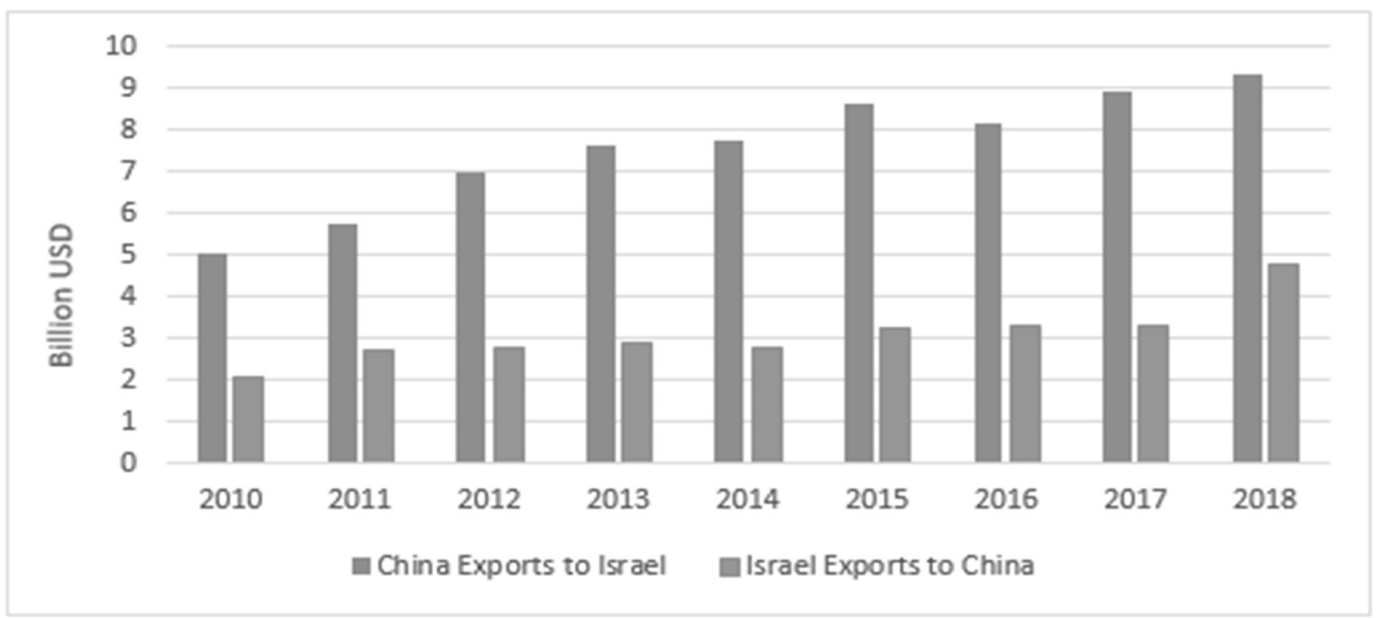

Figure 3: China-Israel bilateral trade volume (2010-2018)

Source: Trade Map, 2018

in wind and solar energies. Israel also invites Chinese companies to participate in Israeli oil and gas exploration (in the Eastern Mediterranean) (Chaziza 2018a: 35).

Another part of China's investment is operating under the Belt and Road Initiative (BRI). Israel is important to China for operationalizing this project because of its geographical location and its advantages as a sustainable partner. Israel's geographical location between the Mediterranean and the Indian Ocean allows China to bypass the Suez Canal and connect the Red Sea to the Mediterranean. Chinese companies spend tens of billions of dollars on transportation projects, construction of docks and customs warehouses in Israel. China's Harbor Pan Mediterranean Engineering Company (PMEC) is building a port next to one of the southern cities of Ashdod on The Mediterranean Coast. Shanghai International Port Group (SIPG) has also obtained a 25 -year contract to construct a port in the north of Haifa. These maritime projects are particularly important for China, which is seeking to diversify sea routes for trade. To start the two projects, a total of $\$ 1$ billion has been invested to be completed by 2021 (Chaziza 2018b: 60-61). The RED-MED rail project from the Israeli Red Sea port town of Eilat to the Israeli port of Ashdod on the Mediterranean ports is also being built by the Chinese which estimates $\$ 6$ billion to $\$ 13$ billion. Through these projects, China is able to easily export its goods to North Africa and Europe, and the Suez Canal will no longer be the only route to trade with the two regions. Another advantage of these projects for China is the employment of more than 20,000 Chinese workers (Evron 2017a; Rajiv 2017: 417).

\section{Desecuritizing Scenarios for Iran}

Although at first glance the development of China-Israel relations is as common as the expansion of relations between many other countries but the regional 
and ideological rivalries between Iran and Israel on the one hand and the strategic vision of Iran to cooperate with China on the other cause the rise of Beijing-Tel Aviv relations to be accompanied by scenarios of threat and desecuritization for Iran.

\section{Scenarios at National Level \\ Threating China - Iran Relations in the Energy Sector}

Energy cooperation is at the heart of China-Iran relations. Iran holds the world's fourth largest oil reserves and one of the world's largest gas reserves, so in this case is one of China's major partners. About 6.3\% of China's oil imports in 2018 came from Iran. China has helped developing the energy industry in Iran since the Islamic Revolution and Tehran has had to turn to Beijing for attracting investments because of international and unilateral US sanctions. China's investment in Iran's energy industry totaled more than $\$ 120$ million in 2007. Some investments have also been canceled under direct US pressure. This shows that China does not want its cooperation with Iran causes any harm to its relations with other countries (Ponížilová 2019: 6). Iran's dependence on China and the pragmatic approach of Beijing will turn Iran into a playing card. Especially since China has already been willing to compromise on $\mathrm{Iran}^{3}$. Israel, that calls for especially economic pressures and restrictions on Iran, could threaten China-Iran energy relations. Israel is seeking to persuade China to cooperate with the United States to put pressures on Iran. Israel could seek US approval for the transfer of some sensitive technologies to China and instead urging Beijing officials to limit their ties with Iran in the energy sector and instead invest in its energy industries in the eastern Mediterranean. China is also easily able to offset the decline in oil imports from Iran by importing other countries, including Saudi Arabia, Russia and Iraq. Table 2 shows China's oil imports from various countries.

Table 2: Top Oil Suppliers to China (2018)

\begin{tabular}{|c|c|c|c|c|c|}
\hline Grade & Country & $\begin{array}{c}\text { The Portion of oil export to } \\
\text { China (\%) }\end{array}$ & Grade & Country & $\begin{array}{c}\text { The Portion of oil export to } \\
\text { China (\%) }\end{array}$ \\
\hline 1 & Russia & 15.8 & 7 & Iran & 6.3 \\
\hline 2 & Saudi Arabia & 12.4 & 8 & Kuwait & 5 \\
\hline 3 & Angola & 10.4 & 9 & Venezuela & 2.9 \\
\hline 4 & Iraq & 9.4 & 10 & USA & 2.8 \\
\hline 5 & Oman & 7.2 & 11 & UAE & 2.8 \\
\hline 6 & Brazil & 6.8 & 12 & Libya & 2 \\
\hline
\end{tabular}

Source: World Export, 2018

\footnotetext{
${ }^{3}$ Ending Nuclear Cooperation with Iran in the 1990s Following Jiang Zemin's and Clinton's agreement and China's joining in the Obama-era comprehensive sanctions on Iran were only some critical points in of China's US reconciliation about Iran.
} 
Another variable that is likely to threaten Iran-China energy relations is the improvement of Arabs relations with Israel. Arab Countries (especially some members of the GCC) and Israel both seek to align with the United States to put pressure on Iran. They can persuade China to cut ties with Iran in the energy sector and are able to offset its share of oil exports to China. Continuation of current trend in foreign policy of the Islamic Republic of Iran will bring Arabs and Israel closer to put pressure on Iran and encourages some powers close to Iran, including China, to make some distances. Although China's policies are based on maintaining regional balance, and it is not seeking to change the balance to the detriment of any party in the region but Iran's current foreign policy makes it unable to enjoy the benefits of a relationship with China and it causes divergences in their relations.

\section{Weakening of Iran-China military relations}

China is one of the largest arms exporters in the world, which sells weapons to various governments regardless of their political system or human rights status. Iran is also one of the most important arms importers from China. Chinese arms sales to Iran began in the 1980s, and during this decade, due to the Iran - Iraq war and Europeans' refusal to sell weapons to Iran, this country became the largest importer of weapons from China. According to Stockholm International Peace Research Institute (SIPRI), Iran purchased annually \$ 174 million of conventional weapons from China until 2004. Another important aspect of the military relationship between the two countries is China's involvement in Iran's missile industry. Beijing has been involved in the sale of missiles to Iran (especially the Silkworm) and the promotion of Iranian technical knowledge in this field (Arghavani 2015: 223-25).

Given China's growing military cooperation with the Middle Eastern countries, one of Israel's key goals in developing relations with China is influencing its proliferation of weapons policies in this region. Israel is concerned that China's advanced military technologies will be made available to its enemies, including Iran and resistance groups. The experience of the 2006 Lebanon War and Hezbollah targeting an Israeli frigate using the Silkworm missile testified Israel's concerns about military technology transfer to Iran and its allies (Xiao 2016: 9-10) This is one of the key factors behind Israel's reluctance to sell military technology to China. Israel has repeatedly urged China to limit its military ties with Iran and not to provide advanced military weapons to this country. Israel's concerns increased after 2019 and following determination for abolition of arms sanctions on Iran from 2020 (based on Joint Comprehensive Plan of Action).

\section{Weakening Iran's position on the Silk Road project}

One of the serious concerns of Israeli officials since offering the China's silk road project with the name of 'One Road, One Belt', is the diminishing impact of sanctions on Iran over its presence in this strategic project. In addition to its high status in the land-use plan in this project, Iran has received informal promises from China for 
investing heavily in transportation and oil and gas industries. ${ }^{4}$. If the alleged volume of investment is made, special developments will take place in these two important infrastructure areas of Iran, that is not in line with the policy of Iran's isolation in the economic sphere which Tel Aviv pursues. Israel, on the other hand, as an alternative to Iran's oil and gas industries has called for Chinese investment in the exploration and extraction of hydrocarbon resources in the eastern Mediterranean to deprive Iran of the investments on the one hand and expand Israel's infrastructure on the other. Continuing widespread sanctions on Iran and Chinese fears of Western punishments and its attempt to portray itself as a responsible actor in the international community reinforces the possibility that, if an active diplomacy is not employed, Iran's predetermined position will be weakened or at least it will pale out which raises the dilemma of fears and hopes about the project and the prospect of China becoming a serious competitor among Iranians (Shariatinia, Azizi 2019: 987-990).

\section{Scenarios at Regional Level}

\section{Changing the regional balance to the detriment of Iran}

The development of China-Israel relations in the regional dimension could change the regional balance to the detriment of Iran. The pragmatic policies of Iran's rivals, including Israel and Saudi Arabia, make them better able to enjoy the benefits of cooperating with Beijing, but given its foreign policy, Iran is unlikely to benefit from cooperating with China in political, economic or military sectors. The divergences discussed at national level for China-Iran relations are also effective at changing regional balance to Iran's detriment. Iran's competitors seek to limit China-Iran relations by strengthening economic and political ties with Beijing. Some factors on Iran's side also reinforce these limitations; a lack of realism in Iranian politics and a misunderstanding of China's Middle East policies will lead to a narrower bilateral China-Iran relationship. While Israel and other Iranian rivals benefit from China's economic-friendly foreign policy and creating an economically attractive domestic environment but Iran in this case is in a weaker position than its rivals.

Iran's Regional Containment: Increased cooperation between China and Israel could lead to Iran's containment in the region. One of Israel's goals for its proximity to China is to influence its Middle East policies. Israel has repeatedly called on China to cut ties with Palestinian groups, including Hamas. In addition to Beijing's donations to these groups, there are reports that some Chinese weapons have been trafficked to these groups (Shai 2011:27). China, on the other hand, is trying to play a more prominent role in presenting itself as a responsible power by encouraging the Palestinians to accept the two-state plan and supporting less radical groups, which means weakening Iran's regional allies. Israel's other goal is to put pressures on Iran. Tel Aviv is trying

\footnotetext{
${ }^{4}$ China and Iran Flesh out Strategic Partnership. URL: https://www.petroleum-economist.com/articles/politicseconomics/middle-east/2019/china-and-iran-flesh-out-strategic-partnership (accessed 20.06.2020)
} 
to limit Beijing relations with Iran by approaching China and convincing this country to put pressure on Iran over its missile and regional role. The persistence of the current tense and unstable situation in the region will also threatens China's economic interests that would turn this country toward Iran's containment in the region. China's integration into the existing international order is another factor that forces China to put pressure on Tehran.

The normalization of Arabs-Israeli relations: One of the axes that is constantly pursued in modern Israeli foreign policy is the attempt to exploit a shared common enemy or a common friend with Arab countries to facilitate normalizing its relations with them. Meanwhile, the growing and improving relations between China and Arab countries have been one of the main centers of attention for Israeli. In addition to strengthening bilateral relations with almost all Arab countries in the last two decades, China has formed multilateral initiatives through joint meetings with these countries and has provided many opportunities for cooperation in various fields. The field could gradually come to the aid of Israel and, through Chinese mediation, provide conditions for gently more Israeli-Arab relations than ever before and also could turn the Palestinian issue into a low priority one and make it just a slogan. In the same vein, given that the Palestinian issue is one of the grounds for justifying Iran's regional presence, if it becomes a normal issue, in the mid-term, Iran's regional influence could be further challenged, and this will naturally be in line with regional goals of Israeli foreign policy.

\section{Scenarios at International Level}

\section{China's conscious passivity and aligning with Pressures Against Iran}

One of Israel's policies to counter Iran is persuasion of close powers to Iran, including China, to put pressure on this country. Israel wants China to limit particularly its economic relations with Iran and to accompany US pressure on this country to normalize its conduct. Given that China does not want to harm its relations with Iran, it is unlikely that China, Israel and the United States will negotiate over Iran. Israel can use its advantages, including advanced military technology, to attract China. Another issue that fuels China's conscious passivity towards Iran is its integration into the existing international order and strengthening of its economic relations with the West. While China seeks to exploit the capabilities of the existing world order, the Islamic Republic continues to oppose it, which will lead to divergence in relations between the two countries. If China aligns with the pressure on Iran in this situation, this would mean consolidating the perception of this country as a threat and it would further isolate it.

Israel's exploitation of China's capacity in international institutions and efforts to legitimizing itself: Since the official launch of diplomatic relations between China and Israel, one of Tel Aviv's key goals in these relations has been to use China's international presence in various institutions and regimes. China has always been a party to bargaining on a variety of international issues as well as establishing new norms and 
regimes within international organizations due to the political power of permanent membership of the Security Council. Thus, developing relations with China helps Isra$\mathrm{el}$, in addition to legitimizing its actions in the disputed territories, diminishes the relevance and importance of the Palestinian issue. Furthermore, one of Israel's challenges in recent years has been the condemnation of international community, especially in the human rights field, but China's presence in these institutions and its strong stance on human rights issues in terms of linking it to national sovereignty can help Israel to reduce pressures or display them differently.

\section{Strengthening the perceptions of Iran as a threat and Continuing Iranophobia:} Attempts to magnify the negativity of Iran's activities and its threats have been among hallmarks of Israel's foreign policy in recent years. Naturally, the success of this policy would be greater when the great powers are aligned with it. To this end, reinforcing the idea of an atomic and ideological Iran that is sensitive about the destiny of Muslims all over the world is one of the issues that has at times occupied the minds of Chinese officials. This approach has been compounded by Beijing officials concerns due to China's sensitivity to the activities of the Uyghurs as well as Iran's vigorous attempt to join Shanghai Organization. So, the development of Israel's comprehensive relations with China and the influence of media and diplomacy on this country could certainly combine with the greater implications of the perception of Iran's threats and weaken the potential for exploiting China's capabilities for Tehran in the future.

The growing relationship between China and Israel has experienced two completely different stages. The first was from 1949 to 1992, and by the early 1970s, thirdparty variables, including the Arabs and the United States, had a negative impact on China-Israel relations. But since the beginning of China's economic transformation, the relationship between the two parties has been gradually improving with considering the benefits two sides. The second phase has begun since 1990s, which has led to the flourishing of relations between the two countries, especially in the economic field. However, Israeli-Chinese relations are one of the issues neglected in Iranian foreign policy. These relations could be coupled with numerous security scenarios for Iran. These relations, at the national level and in the energy and military fields, threaten relations between China and Iran. Iran due to sanctions is looking for China's investment in energy fields. Israel can threaten Iran's energy security by taking these advantages and normalizing relations with Arab countries. In the military field, Israel wants China to restrict the transfer of military technology to its enemies, including Iran. Iran, however, hopes to cooperate with countries such as China and Russia in the area because of the arms sanctions. The repercussions of China-Israel relations at regional level are also significant for Iran. At the regional level, the balance of power shifts to the detriment of Iran because its rivals, including Israel, enjoy the benefits of working with China, but due to inaccurate foreign policy strategies, Iran cannot enjoy the full benefits of working with China and reaches to a weak position particularly in economic terms compared to its competitors. Another consequence is the containment of Iran. Israel seeks to persuade China to put pressures on Iran over its missile projects and 
regional role, and China's economic-oriented view to the region reinforces Iran's containment. Another regional consequence is Israel's attempt to normalize relations with Arabs by focusing on their common friend and enemy or China and Iran respectively. At the international level, the sum of these issues could also lead to China's conscious passive response to pressure on Iran, working with the United States to normalize this country's behavior, Israel's use of China's international capabilities and reinforcing the perception of Iran as a threat.

Given the strategic relations between the United States and Israel, it seems that the US confrontational approach to China during Trump's presidency will cause Israel to be more cautious in developing relations with China. Although before Trump's presidency, the United States treated the growing relations between Tel Aviv and Beijing with a kind of pragmatism and disregard but in the current situation, it seems that the strict approach of the United States toward China and Iran in the same time could reduce the negative aspects of this development of relations for Tehran in the medium term. But it should be noted that this situation will not be sustainable at all because either Trump will not be elected in the next elections or Chinese pragmatism will lead to reconciliation with the United States and thus the continuation of the development of relations with Israel.

At the regional level, the COVID-19 pandemic may lead to conflicting effects. On the one hand, China has become one of the main sources of medical assistance to Middle Eastern countries, including Iran and Israel that are relying on its experience of fighting the virus, and this has strengthened its position in the region. On the other hand, Washington's diplomatic efforts aim to accusing China for concealing the coronavirus outbreak, destroying its reputation and increasing pressure on it. This seems to put Israel in a tight spot in the medium term and put Iran in a better position to take advantage, albeit passively, of existing tensions.

The current trends in relations between China and Israel on the one hand and the persistence of Iran's view of international order and relations with the West on the other hand indicate that Iran's rejection of the existing international order and its attempts to exploit the beneficiaries of this order for facing the current order has been costly and often unsuccessful. For this reason, the development of inter-regional power relations, especially those powers that have a special place in the Iran's looking to east strategy - China and Russia - with countries that are in rival or conflict with Iran, always has adverse consequences in political and security fields. To avoid Iran's isolation and strengthen ties with China, considering some points is essential. First, the Islamic Republic must refrain from relying on a particular power and seek multilateralism and expand relations with the emerging powers. Experiences also show that Iran has always suffered from reliance on a particular power. Second, Iran must extend its relations with emerging powers, including China, beyond the energy sector, and in particular through strengthening economic ties to make them dependent on these relations. The third point is the revision of the security-oriented foreign policy and shifting it to an economy-oriented one. At the same time, the internal environment must 
also be favorable and attractive for economic cooperation. But if the current foreign policy continues, divergence in China-Iran relations would not be surprising.

\section{About the authors:}

Fariborz Arghavani Pirsalami - Assistant professor of International Relations at Shiraz University, Eslami Blvd. Shiraz 71946-84471, Iran. E-mail: farghavani@shirazu.ac.ir (Corresponding Author).

Seyed Javad Salehi - Assistant professor of International Relations at Shiraz University, Eslami Blvd. Shiraz 71946-84471, Iran. E-mail: Salehi_j@yahoo.com

Hosein Alipour - Ph.D Student in Middle East Studies, Shiraz University, Eslami Blvd. Shiraz 71946-84471, Iran. E-mail:h.alipour18@gmail.com

Conflict of interests: The authors declare absence of conflict of interests.

\section{Развитие китайско-израильских отношений после окончания холодной войны: анализ сценариев десекьюритизации Ирана}

Фариборз Аргавани Пирсалами, Сейед Джавад Салехи, Хосейн Алипур DOI 10.24833/2071-8160-2020-3-72-205-224

Ширазский университет, Иран

Важной особенностью внешней политики Израиля после окончания холодной войны стало развитие отношений с развивающимися странами, включая Китай. Акцент на экономическую составляющую во внешней политике обеих стран, усилия Китая по достижению статуса великой державы и стратегия Израиля по улучшению своего глобального имиджа и регионального положения привели отношения двух стран к состоянию полноценного сотрудничества. В статье наряду с описанием отношений между двумя странами в политической, военной и экономической сферах и признанием влияния поведения Китая и Израиля на национальную и региональную безопасность Ирана, делается попытка ответить на следующие вопросы: Каковы показатели развития китайско-израильских отношений в эпоху после окончания холодной войны? Каковы последствия этих отношений для Ирана? С точки зрения этой статьи, развитие китайско-израильских отношений во всех областях идёт по восходящей траектории и, следовательно, имеет существенные последствия для национального (угроза для китайско-иранских отношений в области энергетики, ослабление ирано-китайских военных 
отношений и укрепление позиции Ирана в проекте Шёлкового пути), регионального (изменение баланса в ущерб Ирану, сдерживание Ирана и нормализация арабо-израильских отношений) и международного уровня (сопутствующее давление Китая на Иран, использование Израилем потенциала Китая в международных институтах и усилия по узакониванию и укреплению понятия «угрозы Ирана» и продолжающейся иранофобии) для безопасности Ирана.

Ключевые слова: Китай, Израиль, Иран, Ближний Восток, безопасность, внешняя политика.

\section{6 aвmopax:}

Фариборз Аргавани Пирсалами - доцент кафедры международных отношений в университете Шираз, Шираз, Бульвар Еслами 71946-84471, Иран.

E-mail: farghavani@shirazu.ac.ir (автор для связи)

Сейед Джавад Салехи - доцент кафедры международных отношений университета Шираз, Шираз, Бульвар Еслами 71946-84471, Иран. E-mail: Salehi_j@yahoo.com

Хосейн Алипур - аспирант по изучению Ближнего Востока, Университет Шираз, Шираз, Бульвар Еслами 71946-84471, Иран.E-mail: h.alipour18@gmail.com

Конфликт интересов. Авторы заявляют об отсутствии конфликта интересов.

\section{References:}

Agdemir A.M. 2016. Israel s Rise in Asia: The Relations between Israel and the People s Republic of China. Review of International Law and Politics. 12(1). P. 41-74. DOI: 10.19096/ rilp.2016116719.

Arghavani F. 2015. An Introduction to Strategic Relations between Iran and China in the Light of International Identities. Tehran: Mokhatab.

Fariborz A. 2015. An Introduction to Strategic Relations between Iran and China in the Light of International Identities. Tehran: Mokhatab.

Ayyadi I., Kamal M. 2016. China-Israel Arms Trade and Co-Operation: History and Policy Implications. Asian Affairs 47(2). P. 260-273.

Chau D.C., Kane T.M. 2014. China and International Security: History, Strategy, and 21stCentury Policy. California: Santa Barbara.

Chaziza M. 2018a. Israel-China Relations Enter a New Stage: Limited Strategic Hedging. Contemporary Review of the Middle East. 5(1). P. 30-45. DOI: 10.1177/2347798917744293.

Chaziza M. 2018b. The Chinese Maritime Silk Road Initiative: The Role of the Mediterranean. Mediterranean Quarterly. 29(2). P. 54-69. DOI: 10.1215/10474552-6898099

Dorsey J.M. 2017. China and the Middle East: Venturing into the Maelstrom. Asian Journal of Middle Eastern and Islamic Studies. 11(1). P. 8. DOI: 10.1080/25765949.2017.12023322.

Efron S. et al. 2019. The Evolving Israel-China Relationship. The Evolving Israel-China Relationship. RAND Corporation. DOI: 10.7249/rr2641

Ehteshami A., Horesh N. 2018. China's Presence in the Middle East: The Implications of the One Belt, One Road Initiative. London: Taylor \& Francis Group.

Evron Y. 2013. Between Beijing and Washington: Israel's Technology Transfers to China. Journal of East Asian Studies. 13(3). P. 503-528. DOI: 10.1017/S1598240800008328.

Evron Y. 2017a. OBOR's Impact on Sino-Israeli Relations. China's Presence in the Middle East the Implications of the One Belt, One Road Initiative. Eds. A. Ehteshami and N. Horesh. London: Routledge. P. 120-136. 
Evron Y. 2017b. The Economic Dimension of China - Israel Relations: Political Implications, Roles and Limitations. Israel Affaies. 23(5). P. 828-847. DOI: 10.1080/13537121.2017.1343870.

Goldstein J. 2004. The Republic of China and Israel, 1911-2003. Israel Affairs. 10(1-2). P. 235-237. DOI: 10.1080/13537120412331321441.

Javaid U., Meer W. 2016. China's Foreign Policy in the Middle East. South Asian Studies. 31(2). P. 701-711. http://pu.edu.pk/images/journal/csas/PDF/20_31_2_16.pdf

Jin L. 2017. China's Role in the Middle East: Current Debates and Future Trends. China Quarterly of International Strategic Studies. 3(1). P. 39-55. DOI: 10.1142/S23777440017500014.

Kim I., Mohaisen M. 2016. China's Foreign Policy Towards the Middle East: Trends and Challenges. The Journal of Modern China Studies. 17(2). P. 329-352. DOI: 10.35820/JMCS.17.2.10

Olimat M. 2013. China and the Middle East: From Silk Road to Arab Spring. New York: Routledge.

Ponízilová M. 2019. Foreign Policy Activities of China in the Middle East: Establishing Energy Security or Being a Responsible Emerging Power? Journal of Balkan and Near Eastern Studies. 21(6). P. 1-20. DOI: 10.1080/194489

Rabkin Y.M. 2013. Russia, China and India and the Israel-Palestine Conflict. Holy Land Studies. 12(1). P. 9-24. DOI: 10.3366/hls.2013.0057.

Rajiv S.C. 2017. Israel-China Ties at 25: The Limited Partnership. Strategic Analysis. 41(4). P. 419, DOI: 10.1080/09700161.2017.1330942 P. 413-431. doi.org/10.1080/09700161.2017.1330 942.

Sazmand B., Arghavani F. 2017. Global and Regional Foreign Policy of China in the 21st Century. Tehran: University of Tehran Press.

Scobell A. 2018. Why the Middle East Matters to China. China's Presence in the Middle East the Implications of the One Belt, One Road Initiative. Ed. by A. Ehteshami and N. Horesh. London: Taylor \& Francis Group.

Shai A. 2011. Sino-Israeli Relations: Current Reality and Future Prospects. Journal of Middle Eastern and Islamic Studies (in Asia). 5(2). P. 17-42. DOI: 10.1080/19370679.2011.12023178

Shai A. 2014. China and Israel: Relations and Future Prospects. ASPJ Africa \& Francophonie. 5(2). P. 66-86.

Shai A. 2019. China and Israel: Chinese, Jews. Beijing, Jerusalem (1890-2018). Israel Journal of Foreign Affairs 13(2). P. 226-229. DOI: 10.1080/23739770.2019.1651983.

Shariatinia M., Azizi H. 2019. Iran and the Belt and Road Initiative: Amid Hope and Fear. Journal of Contemporary China. 28(120). P. 984-994. DOI: 10.1080/10670564.2019.1594108

Shichor Y. 1998. Israel's Military Transfers to China and Taiwan. Survival. Informa UK Ltd. P. 68-91. DOI: 10.1093/survival/40.1.68.

Shichor Y. 2015. Chinese-Israeli Relations in a Middle Eastern Context: Retrospect and Prospects. Mediterranean Quarterly. 26(1). P. 137-151. DOI: 10.1215/10474552-2873021

Sufott E.Z. 2000. Israel's China Policy 1950-92. Israel Affairs. 7(1). P. 94-118. DOI: $10.1080 / 13537120008719591$.

Xiao X. 2016. The "Belt and Road Initiative" and China-Israeli Relations. Journal of Middle Eastern and Islamic Studies (in Asia). 10(3). P. 1-23. DOI: 10.1080/19370679.2016.12023285. 